\title{
Psychological Capital and Performance of Secretarial Personnel in ICT-Based Organizations (A Study of National Institute of Information Technology and Ministry of Information, Port Harcourt, Rivers State)
}

\author{
ANELE, Clement A. Ph.D., MABEN \\ Department of Business Admin., Niger Delta University, Wilberforce Island, Bayelsa \\ State, Nigeria \\ Tel: 234-807-074-6570Ｅ-mail: anele.clementanuba@gmail.com \\ Micheal King Atimi-Yousuo \\ Department of Business Administration,Niger Delta University, Wilberforce Island, \\ Bayelsa State, Nigeria \\ E-mail: atimiyousuo@gmail.com \\ Kenebara, Florence Aniambrade \\ Department of Business Administration, Niger Delta University, Wilberforce Island, \\ Bayelsa State, Nigeria \\ E-mail: floxygede@gmail.com
}

Received: Dec. 5, 2017 Accepted: December 11, 2017 Published: December 31, 2017

doi:10.5296/bms.v8i2.12398ＵRL: https://doi.org/10.5296/bms.v8i2.12398

\begin{abstract}
This study focused on Secretarial Performance, Engagement and Development through Psychological Capital of Secretarial Personnel in ICT-Based Organizations- National Institute of Information Technology and Ministry of Information, Port-Harcourt, Rivers State. The




\section{Macrothink}

study employed the descriptive research design. Population of the study comprises secretarial staff and their bosses in National Institute of Information Technology, and Ministry of Information in Port-Harcourt, Rivers State. A sample size of 54 staff were randomly selected. Findings show that for management of the organizations to achieve organizational objectives, it must not only make use of both human and non- human resources in its disposal, and should also develop and train employee's psychological capital. Based on the findings of the study, it recommends that factors that make positive psychological capital should be outstanding and treated with great care. Also, training programmes and facilities should be structured in organizations to enhance the psychological state of secretaries.

Keywords: Psychological capital, performance, secretarial personnel, organization. 


\section{Introduction}

The management of any organization is saddled with the responsibility of achieving the objectives of the organization in an effective and efficient manner. This will be accomplished if management utilizes the resources and its disposal i.e. both human and non-human resources properly. An optimal combination and the use of these resources is required for the achievement of the objectives of the organization. In psychology, there has been concern and debate on the relative emphasis and conceptualization of the situational based state like source, psychological capacities versus the relatively fixed trait-like personality constructs. To date, there has been a death of studies, examining the role of that individual positive state; such as hope, optimism, self-efficacy and resilience can play on employee performance, and there has been no research on the overall positive psychological capital can play in predicting the performance of worker (Secretarial Personnel).

Modern psychology started with the charge not to help secretaries with problems, but also identify and build strength in people, through years. Virtually, all the attention has been developed to mental illness with what is wrong with people and how to repair the damage.

Luthans and Youssef (2004), proposed that psychological capital goes beyond the now widely recognized human capital (what you know) and social capital (who you know), and is basically "who are you". At the individual level psychological capital is a psychological resource that fuel growth and performance of secretarial personnel in any organization. At the organizational level, similar to human and social capital, psychological capital may provide leverage, return on investment, and competitive advantage; through improved employee performance. Luthane and Youssef (2004) have empirically confirmed that positive psychological capital outcome has improved on the performance of employees and subsequently improved the chance of actualization of organizational objectives.

The objective of this paper is to identify whether a relationship exists between hope, resilience, optimism, and self-efficacy on the performance of secretarial personnel in the Information Technology Based Organizations.

\subsection{Statement of Problem}

Psychological capital started with the charge not only to help secretaries with problems, but also identify strengths in people; through the years. Virtually, all attention has been devoted to mental illness; what is wrong with people, and how to repair the damage. Management has a great job in finding out what factors that will boost the positive psychological capital (hope, resilience, optimism and self-efficacy) of secretarial personnel performance.

Over time, many organizations have collapsed because of the inability of management to notice or identify the core construct of psychological capitals which are; hope, confidence, optimism and resilience as ways of improving and developing employees' performance, and this has led to the fall of these organizations and the attendant effects on the economy. 
1.2 Purpose of the Study

The general objective of this study is to find out the impact of psychological capital on the performance of secretarial personnel on information and communication based organization.

Specifically, the objectives include:

1. To find out whether the confidence exhibited by secretaries affect their performance in ICT organizations in Rivers State.

2. To find out the effect of their resilience of secretaries on their performance in ICT organizations in Rivers state.

3. To ascertain whether their optimism has positive influence on secretarial employees, performance in ICT organizations in Rivers state.

4. To find out whether hope can positively influence secretarial employees’ performance.

\subsection{Research Questions}

The study seeks to find satisfactory answers to the following questions:

1. To what extent does confidence influence secretarial personnel performance in ICT organizations in Rivers state?

2. To what extent does resilience influence secretarial performance in ICT organizations in Rivers state?

3. To what extent does optimism influence the performance of secretarial personnel in ICT-based organizations in Rivers state?

4. To what extent does hope influence the performance of secretarial in ICT-based organizations in Rivers state.

\subsection{Significance of The Study}

This study will be of immense significant and benefit to the management, secretarial employees, academicians, and the general public, at large.

The management of the organization is saddled with the responsibility of ensuring that organizational objectives must be accomplished.

The management can therefore use the findings of this study to know what factors that make positive psychological capital useful to secretaries on their job performance.

The findings of this study will also be beneficial to secretarial personnel. It will help them to know the factors that are likely to boost their hope, confidence, optimism and resilience to work in optimal manner.

The public will also benefit from the study in the sense that, people who are faced with stress at work will be able to identify the factors that can lead high office performance and then contribute to economic growth. 
By eschewing a preoccupation with personal short comings and strengths and good qualities, today's leaders and their associates can develop confidence, hope, optimism and resilience, thereby improving both the individual and the organization's performance.

Finally, the findings of this study will help secretarial personnel play their roles effectively and efficiently in the organization.

\section{Review of Related Literature}

\subsection{Background and Meaning of Psychological Capital}

In psychology, there has been concern and debate on the relative emphasis and conceptualization of the situationally based, state-like source, psychological capacities versus the relatively fixed trait-like personality constructs. To date, there has been a dearth, couple of studies, examining the role that individual positive psychological state, such as hope, optimism, self-efficacy and resilience can play on employee's performance, and there has many research on the role that overall psychological capital can play in predicting the performance of employees.

Although, modern psychological started with the charge to not help with problems, but also identify and build strengths in people (employees). Initially, the theory-building for positive organization behaviour identified and supported confidence, hope, optimism and resiliency, and their relationship to leadership. Drawing from positive psychology, Seligman (2000), noted that the positive organizational behaviour approach incorporates over looked state-like positive psychological strengths and capacities. These positive states, which in aggregate are referred to as core factor of psychological capital may have important implications for employee work motivation and authentic leaderships.

Luthans (20026.P.59), specifically defines positive organizational behaviour as the study and application of positively oriented human resource strengths and psychological capacities of employees that can be measured, developed and effectively managed for performance improvement in today's work place.

\subsection{Capacity Concept of Positive Psychological Capital}

Psychological capital goes beyond human and social, and basically consists of "who you are”, rather than "what you know". Specifically, we are referring to the four positive psychological capacities of confidence, hope, optimism, and resilience (Stakiikovic, 2003).

Drawing from positive psychology and more recently, what we have termed "positive organizational behaviour", such capacities are measurable, open to development and can be managed for more effective work performance by secretarial employees. According to Luthans (2006), the following paragraphs briefly summarize these four states as they apply to today's workplace and contribute to positive psychological capital, with a return of improved performance; such as higher productivity, better customer service and more employee retention for secretarial personnel. 
i. Confidence: Staskovie and Luthans (1998), defines confidence (or self-efficacy) of secretarial personnel as the "individuals" conviction about his or her abilities to mobilize the motivation, cognitive resources, and courses of action needed to successfully execute a specific task within a given context”.

Beginning with the considerable theory and research of well-known psychologist, Albert Bandura, Confidence as a positive-psychological capital capacity has been demonstrated to have a strong positive relationship to work-related performance. Moreover, Bandura (1997) and others have clearly shown through empirical studies that high self-efficacy often have higher job performance.

ii. Hope: hope makes an important contribution to positive psychological capital. Snyder, et.al (1991) defined psychological capital as "a positive motivational state that is based on an interactively derived sense of successfulness.

a. Agency (goal-oriented energy) and

b. Pathways (planning to meet goals).

Although on the surface, hope appears very similar to the other positive capacities, considerable theoretical and measurement analysis demonstrate its conceptual independence and discriminate validity in particular, the pathways or "war power", dimension of hope as defined here makes an important differentiation with the common use of the term and other psychological capital capacities. There is considerable evidence of positive impact on academic and job performance. However, only a few direct and indirect studies, including Adams et. Al (2003) and Peterson and Luthans (2003), have examined its impact on workplace performance. Nevertheless, these workplace studies are promising.

iii. Optimism: optimism is perhaps more closely associated with overall positive psychology than the other constructs. Like hope, optimism is a commonly used term, but Seligman's (2002) drawn from attribution theory in terms of two crucial dimensions of one's explanatory style of good and bad events: Performance and Perverseness.

Specifically, optimists interpret bad events as being only temporary (I'm exhausted), while pessimists interpret bad events as being permanent (I'm all washed up). The opposite is true for good events for which the optimist makes a permanent attribution (I'm talented) and the pessimist a temporary attribution (I tried very hard on this one).

Whereas permanence has to do with time, perverseness has to do with space. Seligman (1998) provides some evidence of the positive impact of measured optimism on desirable workplace outcome, reporting secretarial personnel on high performance and retention of the metropolitan life insurance company.

iv. Resilience: through a mainstay of positive psychology coming mostly out of child psychology, resilience has received scant attention in organizational behaviour and human resource management research. Yet, this capacity to "bounce back" from adversity or even dramatic positive changes is particularly relevant in today's turbulent business environment. 
At first, resilience was thought to be quite rare in people, but now says Masten (2001), there is evidence that it can come "from the everyday magic of ordinary, normative human resources”, and has performed implications for promoting competence and human capital in individuals and society”.

According to Coucu (2002), the common themes/profiles of resilient people are now recognized to be:

a. A staunch acceptance of reality,

b. A deep belief, often to be buttressed by strongly held values, that life is meaningful, and

c. An uncanny ability to improvise and adapt to significant change. Except for its application to stress resistance, only surface attempts have been made to use resilience to advocate how secretarial personnel, and employee's overall organization can bounce back from hard times. However, the rich theory and extensive research from clinical and positive psychology, suggest that resilience too, like its three counterparts, can contribute to positive psychological capital with a return of desired outcomes.

\subsection{Positive Organizational Behaviour and Psychological Capital}

Besides theoretical understanding of resources and wellness, the meaning and theoretical foundation for positive organizational behaviour in general and psychological capital in particular must also be provided for the early study. As early as 1954, Maslow had argued that psychology tended to focus more on the "darker" Meaner half" of its potential. He proposed the field should be more balanced in areas such as growth, contentment, optimism, and actualization of human potential. Positive psychology, calling for more balance and focus on the positive as an academic domain of scholarly activity has introduced into the literature with a special issue of the American psycologist, edited by Seligman and Csikzentimihalyi (2000).

This special issue contained positive constructs, such as hope, adaptive mental medicencisms, optimism, objective well-being, employee development and happiness.

Luthans (2002a, 2000, b) introduced the term positive organizational behaviour to bring this positive psychology to the workplace. Although, recognizing that the field of organizational behaviour had given more recognition to a positive than had psychology as a whole. Luthans (2002a), defined positive organizational behaviour as the study and application of positively oriented human resource strengths and psychological capabilities that can be measured, developed, and effectively managed for performance improvement in today's workplace. The emphasis on performance impact and state, like psychological capacities have received attention in the current and future directions highlighted in organizational health psychology research.

In positive organizational behaviour, Luthans and Colleagues (2004), identified the positive constructs of efficacy, hope, optimism, and resilience as at least initially best meeting the inclusion criteria and in combination termed "psychological capital". This psychological capital is defined as:

An individual's psychological state of development that is characterized by 
(i) Having confidence (self-efficacy) to take on and put in the necessary effort to succeed at challenging tasks

(ii) Making a positive attribution (optimism) about succeeding now and in the future

(iii) Persevering towards goal, and when necessary redirecting paths to goals (hope), in order to succeed; and

(iv) When beset by problems and adversity sustaining and bouncing back and even beyond (resilience to attain success (Luthans, Youssef and Ayalio, 2007).

The above definitions predict desired employee outcomes, such as performance and job satisfaction better than the individual resources independently.

Thus, the four proposed components combined into psychological capital, aimed at fostering cognitive evaluations of the availability of resources as indicators iin one's global assessment of wellness. Employees' positive psychological capital reinforces the potential value of their taking different perspectives, appraising situations and circumstances in more positive opportunistic adaptive and promotion/approach focused ways, thus enhancing their well-being.

\subsection{Mechanisms of Motivation on Performance of Secretarial Personnel on Organizations}

Anele (2014), noted that in organization structure, the position and the secretary's presence and the interpersonal function of the organization. Most of the people which managers of an organization communicate with, first meet the secretary. The secretary also stands as a link between the organization and its stakeholders as well as the public. Motivation is one of the widely discussed determinants of individual performance in the management literature.

Hardly is any academic discourse made in the area of organizational theory, organizational behaviour, industrial employee or work motivation. Other determinants of performance apart from motivation are ability, effort expended and previous work experience (Gibson, Levich and Domelly 1976).

Work motivation is regarded as a very important and highly indispensable human resource factor in organizations and the world over. Motivation centers on individuals at work. Managers are expected to understand the existing types and degrees of motivation in their employees and must also try to enhance the extent of motivation demonstrated in diverse as in many respects (Maslow, 1954). This diversity results in different behavioural patterns that in some manner are related to needs and goals. A need in this situation means some internal state that makes certain outcomes appear attractive. An unsatisfied needs creates tension that stimulates drives within an individual. These drives generate search of behaviour to find particular goals that if attuned, will satisfy the need and reduce the tension (1900 et. al; 2004). It could also be regarded as a deficiently or lack of something of value that an individual experience in a particular point in time.

Deficiencies may be psychological (e.g. a need for food) or sociological (e.g. a need for social interaction). Needs are energizers or triggers of behavioural response. The implication 
is that when needs deficiencies are present, the secretarial personnel will seek to fulfill those needs and may be more susceptible to managers' motivational efforts (Maslow, 1954).

Motivated employees are always in a state of tension. The greater the tension, the higher the effort level. If this effort leads to satisfaction of the needs, it reduces tension, because the interest is on work behaviours. This tension reduction effort must be directed towards organizational goals.

\section{Materials and Methods Used}

\subsection{Research Design}

A survey research design was adopted for this study. Reason being that, it offers the research the opportunity to have a wide spectrum of the population as a basis for more accurate generalization.

\subsection{Population and Sample Size}

The population of this study comprises the secretarial staff and their bosses in National Institute of Information Technology, and Ministry of Information and Communication Technology, Port-Harcourt, Rivers State. The sample size was made up of 54 personnel.

\subsection{Instrument for the Study}

The instrument used for this study was structured questionnaire with open and close-ended questions

\subsection{Validity of Instrument}

The validity of the instrument was done on the face value of the questionnaire items. The instrument was given to two experts on the field for proper assessment. The questions were critically examined and validated by a senior colleague. Errors were corrected before distribution was made to deserving respondents. By this, the instrument was subjected to face validity, therefore, making it valuable.

\subsection{Administration of Study Instrument}

The administration of the instrument was carried out by hand. A total of 6o copies of the questionnaire was administered to all respondents. A period of two weeks was given to respondents to fill and 54 copies were retrieved.

\subsection{Method of Data Analysis}

For the analysis of the findings, the simple percentage method was used in computing the responses. This involves the use of tables for clarity. 


\section{Findings/Discussion of Findings}

Table 1. Administering of Research Instrument

\begin{tabular}{|l|r|r|r|r|}
\hline Name of Organization & \multicolumn{1}{|l|}{$\begin{array}{l}\text { No } \\
\text { Issued }\end{array}$} & $\begin{array}{l}\text { No } \\
\text { Retrieved }\end{array}$ & $\begin{array}{c}\text { No } \\
\text { Lost }\end{array}$ & Percentage \\
\hline National Institute of I.T., P.H. & 30 & 28 & 2 & 52 \\
\hline $\begin{array}{l}\text { Ministry of Information } \\
\text { \&communications }\end{array}$ & 30 & 26 & 4 & 48 \\
\hline Total & 60 & 54 & 6 & 100 \\
\hline
\end{tabular}

Source: Research Data 2017.

From Table 1 above, 30 copies of the questionnaire were given to respondents in National Institute of Information Technology Port-Harcourt, while 28(52\%) copies of the questionnaires were retrieved. Similarly, 30 copies of the questionnaires were distributed to respondents in the Ministry of Information and Communication Technology (ICT Department), while a total of 20 copies were retrieved.

Research Question 1: to what extent does confidence influence secretarial personnel performance in ICT-Based organizations?

Table 2. Effect of confidence on secretarial personnel performance.

\begin{tabular}{|c|c|c|c|c|c|c|c|c|c|c|c|}
\hline & Questionnaire Details & $\begin{array}{l}\text { VG } \\
\text { E }\end{array}$ & $\%$ & $\begin{array}{l}\mathbf{G} \\
\mathbf{E}\end{array}$ & $\%$ & $\begin{array}{l}\mathbf{N} \\
\mathbf{E}\end{array}$ & $\%$ & $\begin{array}{l}\mathbf{N} \\
\mathbf{A}\end{array}$ & A & $\begin{array}{l}\text { Tota } \\
\text { l }\end{array}$ & $\%$ \\
\hline 1 & $\begin{array}{l}\text { To what extent do you } \\
\text { demonstrate confidence when } \\
\text { performing your duties? }\end{array}$ & 25 & 46 & 19 & $\begin{array}{l}3 \\
5\end{array}$ & 10 & $\begin{array}{l}1 \\
9\end{array}$ & - & - & 54 & 100 \\
\hline 2 & $\begin{array}{l}\text { As a secretary with confidence, } \\
\text { do you work with independence } \\
\text { when performing your duties? }\end{array}$ & 19 & 35 & 15 & $\begin{array}{l}2 \\
8\end{array}$ & 13 & $\begin{array}{l}2 \\
4\end{array}$ & 7 & 12 & 54 & 100 \\
\hline 3 & $\begin{array}{l}\text { To what extent does the } \\
\text { confidence exhibited by you } \\
\text { influence your job performance? }\end{array}$ & 22 & 41 & 17 & $\begin{array}{l}3 \\
1\end{array}$ & 15 & $\begin{array}{l}2 \\
8\end{array}$ & - & - & 54 & 100 \\
\hline 4 & $\begin{array}{l}\text { To what extent are your office } \\
\text { equipment good to improve your } \\
\text { performance? }\end{array}$ & 18 & 33 & 19 & $\begin{array}{l}3 \\
5\end{array}$ & 9 & $\begin{array}{l}1 \\
7\end{array}$ & 8 & 15 & 54 & 100 \\
\hline
\end{tabular}

Source: Survey Data: 2017

From table 2 above, 25 or $45 \%$ of the respondents were of the opinion that secretaries do demonstrate confidence when performing duties to a very great extent and 19 or 35\% agreed to a great extent, while 10 or $19 \%$ of the respondents judged to a negligible extent, and no responses for "not at all”.

On the independent level, 19 or $35 \%$ of the respondents were of the view that secretaries perform their duties independently, to a very great extent, and 15(28\%) supported to a great extent, while 13 or $24 \%$ ticked to a negligible extent, while $7(12 \%)$ said "not at all”. 
Furthermore, in the aspect of confidence exhibited by secretaries, responses depict that 28 or $41 \%$ of the respondents agreed to a very great extent and $17(31 \%)$ supported to a great extent, while 15 or $28 \%$ were of the opinion of negligible extent, and no response for "not at all".

Lastly, 18 or $33 \%$ of the respondents said their office equipment was good enough to make them perform better to a very great extent, and 19(35\%), supported to a great extent, while 9 or $17 \%$ of the respondents were of the view to a negligible extent and $8(15 \%)$ supported that their office equipment was not good at all to make them perform better.

Research Question 2: to what extent does resilience influence secretarial personnel performance?

Table 3. Effect of resilience on secretarial performance

\begin{tabular}{|c|c|c|c|c|c|c|c|c|c|c|c|}
\hline & Questionnaire Details & VGE & $\%$ & GE & $\%$ & NE & $\%$ & NA & A & Total & $\%$ \\
\hline 5 & $\begin{array}{l}\text { To what extent do you as a } \\
\text { resilient secretary work } \\
\text { harder when faced with work } \\
\text { harder when faced with work } \\
\text { pressure and stress? }\end{array}$ & 13 & 24 & 19 & 35 & 12 & 22 & 10 & 19 & 54 & 100 \\
\hline 6 & $\begin{array}{l}\text { To what extent can } \\
\text { self-resilience be achieved } \\
\text { through participation and } \\
\text { empowerment? }\end{array}$ & 14 & 26 & 16 & 30 & 14 & 26 & 10 & 19 & 54 & 100 \\
\hline 7 & $\begin{array}{l}\text { To what extent can } \\
\text { self-resilience be achieved } \\
\text { when given higher task to } \\
\text { perform }\end{array}$ & 22 & 41 & 17 & 31 & 9 & 17 & 6 & 11 & 54 & 100 \\
\hline 8 & $\begin{array}{l}\text { From the, is there any } \\
\text { positive relationship between } \\
\text { psychological capital and } \\
\text { performance? }\end{array}$ & 13 & 24 & 25 & 46 & 6 & 11 & 10 & 19 & 54 & 100 \\
\hline
\end{tabular}

Source: Survey Data; 2017.

From table 3 above, 13 or $19 \%$ of the respondents stated that resilience secretaries can work harder when faced with work pressure and stress to a very large extent, and 19(35\%) supported to a great extent, while 12 or $22 \%$ judged to a negligible extent, 10(19\%) said "not at all”.

More so, 14 or $26 \%$ of the respondents were of the view that self-resilience can be achieved through participation in work activities and empowerment to a very great extent and 16 or $30 \%$ stated to a great extent, while $14(26 \%)$ of the respondents judged to a negligible extent and 10 or $19 \%$ supported "not at all".

Furthermore, 22 or $41 \%$ of the respondents said self-resilience can be achieved when given higher task to a very great extent, and 17 or $31 \%$ suggested to a great extent, while $9(17 \%)$ stated to a negligible extent, and 6 or $11 \%$ ticked "not at all”.

Finally, 13 or $24 \%$ of the respondents were of the opinion that there is a relationship between psychological capital and performance of secretarial personnel to a negligible extent and 


\section{Ml Macrothink}

$10(19 \%)$ of the respondents stated "not at all” (there is no relationship between psychology and performance).

Research Question 3: to what extent does optimism influence Secretarial personnel?

Table 4. Influence of optimism on secretarial personnel performance

\begin{tabular}{|l|l|l|l|l|l|l|l|l|l|l|l|}
\hline & Questionnaire Details & VGE & \% & GE & \% & NE & \% & NA & A & Total & \% \\
\hline 9 & $\begin{array}{l}\text { To what extent have you been sent for training } \\
\text { programmes to improve your performance } \\
\text { since you were employed? }\end{array}$ & 7 & 13 & 8 & 15 & 18 & 33 & 21 & 39 & 54 & 100 \\
\hline 10 & $\begin{array}{l}\text { To what extent is your office conducive to } \\
\text { make you perform optimally? }\end{array}$ & 10 & 19 & 12 & 22 & 14 & 26 & 18 & 33 & 54 & 100 \\
\hline $\begin{array}{l}\text { Being optimistic about the future, to what } \\
\text { extent does it enable a secretary to function } \\
\text { better? }\end{array}$ & 13 & 24 & 10 & 19 & 6 & 11 & 25 & 46 & 54 & 100 \\
\hline $\begin{array}{l}\text { To what extent can improved performance } \\
\text { improve the chances of achieving personnel } \\
\text { goals? }\end{array}$ & 15 & 28 & 19 & 35 & 13 & 24 & 7 & 12 & 54 & 100 \\
\hline
\end{tabular}

Source: Research Data, 2017.

From table 4 above, 7 or $13 \%$ of the respondents said they have been sent for training programmes to improve on their job performance to a very great extent. 8 or $15 \%$, supported to a great, while $18(35 \%)$ of the respondents stated to a negligible extent, and 21 or $39 \%$ of the respondents said "not at all” (secretaries have not been sent for training programmes regularly).

Again, 10 or $19 \%$ of the respondents were of the opinion that their office environment is conducive/good to a very great extent, and 12 or $22 \%$ supported that it is good to a great extent. In the contrary, $14(26 \%)$ of the respondents stated to a negligible extent, and 18 or $33 \%$ said their office environment is not good at all.

More so, in response to optimism, 13 or $24 \%$ of the respondents ticked that secretaries who are optimistic can function optimally to a very great extent. Another 6 or $11 \%$ of the respondents were of the opinion to negligible extent, while 25 or $46 \%$ of the respondents stated that being optimistic cannot make them to function optimally.

Lastly, 15 or $28 \%$ of respondents accepted that their improved performance can lead them to achieving organization goal to a great extent, and 19 or $35 \%$, supported to a great extent, while $13(24 \%)$ ticked to a negligible extent, and 7 or $12 \%$ said “not at all”.

Research Question 4: to what extent does hope influence secretarial personnel performance?

Table 5. Influence of hope on performance

\begin{tabular}{|c|c|c|c|c|c|c|c|c|c|c|c|}
\hline & Questionnaire Details & VGE & $\%$ & GE & $\%$ & NE & $\%$ & NA & A & Total & $\%$ \\
\hline 13 & $\begin{array}{l}\text { To what extent do you agree } \\
\text { that being hopeful can } \\
\text { improve your performance at } \\
\text { work? }\end{array}$ & 14 & 26 & 16 & 30 & 10 & 19 & 14 & $\begin{array}{l}2 \\
6\end{array}$ & 54 & $\begin{array}{l}10 \\
0\end{array}$ \\
\hline
\end{tabular}




\begin{tabular}{|l|l|l|l|l|l|l|l|l|l|l|l|}
\hline 14 & $\begin{array}{l}\text { How does your health and } \\
\text { psychological status affect } \\
\text { your level of hope? }\end{array}$ & 18 & 33 & 19 & 35 & 8 & 15 & 9 & 7 & 54 & 0 \\
\hline 15 & $\begin{array}{l}\text { What extent does positive } \\
\text { psychological capital } \\
\text { influence employee and } \\
\text { organizational performance? }\end{array}$ & 17 & 31 & 22 & 41 & 9 & 17 & 6 & 1 & 54 & 0 \\
\hline & $\begin{array}{l}\text { From the above, is there any } \\
\text { relationship between hope } \\
\text { and health that could aid } \\
\text { better understanding? }\end{array}$ & 12 & 12 & 15 & 28 & 14 & 26 & 13 & 4 & 54 & 0 \\
\hline
\end{tabular}

Source: Research Data, 2017

From table 5 above, 14 or $26 \%$ of the respondents agreed that of secretaries are hopeful for achievement in the future, it can improve their performance and attitude towards work to a very great extent and 16 or $30 \%$, supported to a great extent. 10 or $19 \%$ of the respondents opted to a negligible extent, while 14 or $26 \%$ stated "not at all".

Again, in the aspect of health and psychological status, 18 or 33\% of the respondents were of the opinion that their health and psychological status have effect on their hope live to a very great extent, and 19 or $35 \%$, supported to a great extent. 8 or $15 \%$ of the respondents, judged to a negligible extent, while 9 or $17 \%$ of the respondent stated "not at all” (health and psychology do not have any effect on their hope level).

More so, 17 or $31 \%$ of the respondents, agreed that positive psychological capital, influence both employee and organizational performance to a very great extent, and 22 or $41 \%$, supported to a great extent. 9 or $17 \%$ of the respondents were of the opinion to a negligible extent, while 6 or 11\%, supported "not at all” (positive psychological capital does not affect both employee and organizational performance).

Finally, in response to whether there is any relationship between hope and health that could enhance better understanding as a secretary, 12 or $22 \%$, of the respondents, ticked to a very great extent, 15 or $28 \%$, supported to a great extent. While 14 or $26 \%$ of the respondents, supported to a negligible extent, and 13 or $24 \%$, said "not at all”.

\subsection{Discussion of Findings}

From the analysis of findings of table 2, and based on the cumulative of "great extent options”, it has found that secretaries who exhibit confidence work independently without supervision. Also, confidence as one of the constructs, has positive influence on employees' performance. Therefore, secretaries tend to be productive when they have confidence and good office environment. From table three of this study, it was found that secretaries in these organizations, tend to achieve and enhance resilience through participation, when given higher task to perform, and also, when faced with pressure and stress. Still, from the cumulative of a (very great extent and great extent), there seem to be positive relationship between psychological capital and permanence. 


\section{Macrothink

Furthermore, findings show that from the study secretaries in these organizations are not sent for training regularly working environment is unconducive, their take home packages, salaries and other financial benefits are not considered seriously. These are the things that demoralize psychology, and its adverse effect on performance.

Finally, findings from the study show that employees who are psychologically imbalanced and do not have good health have negative effect on attitudinal, behavioural and performance outcomes at work. It is therefore, necessary for organizations to develop employees' self-efficacy, fostering hope, enhancing optimism and improving emotional intelligence and thus enhances their work well-being and job performance.

\section{Conclusion}

This study provides preliminary evidence that psychological capital may be a positive resource used to enhance employee performance. While well-being has been shown to have reciprocal effects on work related outcomes, such as job satisfaction, the means of understanding and affection. These reciprocal processes have received little attention. To that end, rational from positive psychology, conservation of resources, and psychological resource theories, in general, provide a theoretical grounding, to better underling of the mechanisms by which this reciprocal interaction may be fostered. The relationship found in this study between psychological capital and performance over time provides an important potential construct in which to influence well-being and better understanding of its impact on more explicit occupational health outcomes.

Organizations should focus on how to develop employees' confidence, fostering hope, enhancing optimism, improving the psychological construct, and other support strategies, and also train staff and thus enhance their well-being, and job performance.

\subsection{Recommendations}

Based on the findings and conclusion, the following recommendations are preferred:

1. Secretaries should be sent for training programmes regularly;

2. The working equipment, and environment should be improved on.

3. Training programmes and facilities should be structured to enhance the psychological state of secretaries;

4. Factors that make positive psychological capital should be outstanding and treated with great care;

5. Secretaries should be highly motivated as they play multiple roles in the organization they serve;

6. Government should improve the general welfare of secretaries, as they are the hub of any society.

\section{References}




\section{Macrothink}

Abba, E. U., Anezodo, R. O., \& Okoye, J. C. (2004). Management \& Organizational Behaviour: Theories \& Applications in Nigeria. Awka: Abbot Books Ltd.

Anele, C. A. (2014). Fundamentals of Industrial \& Labour Relations. Enugu: Rhyle Kerex Publishers.

Bandura, A. (1997). Social Cognitive Theory of Personality. In Handbook (2 ${ }^{\text {nd }}$ ed.): Pervin and O. John, 154-196.

Coutu, J. L. (2002). How Resilience Works. Harvard Business Review, 80(5), 46-55.

Luthans, D., \& Youssef, C. M. (2004). Human, and Social Psychological Capital Management Investment in People for Competitive Advantage Organizational Dynamics, 33, 100-143.

Luthans, F. (2006). The Need for and Meaning of Organizational Behaviour, 23, 695-906.

Luthans, F., Youssef, C. M., \& Avolio, B. J. (2007). Psychological CapitalUK: Oxford University Press.

Maslow, A. (1954). Motivation and Personality. New York: Harper and Row Publishers.

Mastern, A. S. (2001). Resilience Process in Development. American Psychologist, 56(3), 227-239.

Seligman, M. E. P. (2002). Authentic Happiness. New York.

Snyder, C. R., Irving, L. M., \& Anderson, J. R. (1991). Hope and Health. New York: Pergemon Press.

Staskovil, A. D. (2003). Introducing Positive Psychology to Work Motivation: Development of a Core Confidence Model in Organizational Behaviour, 20, 120-135.

Staskovil, A., \& Luthans F. (1998). Social Cognitive Theory and Self-Efficacy. Organizational Dynamics, 26, 62-74.

\section{Copyright Disclaimer}

Copyright for this article is retained by the author(s), with first publication rights granted to the journal.

This is an open-access article distributed under the terms and conditions of the Creative Commons Attribution license (http://creativecommons.org/licenses/by/3.0/). 